\title{
Design and Analysis of The Strength of Rice Transport Vehicle Frames
}

\author{
Daniel Parenden, and Cipto Cipto* \\ Department of Mechanical Engineering, Faculty of Engineering, Universitas Musamus, Merauke 99600, Indonesia
}

\begin{abstract}
Merauke Regency is one of the largest rice producers in Papua Province with a total production of 344,192.32 tons in 2020, a harvested area of 61,584 ha and a rice productivity of 5.59 tons/ha. Agricultural development in Merauke Regency is supported by the availability of agricultural land and the modernization of agricultural equipment. The post-harvest process is the final phase that is key to success, so it must be handled properly to achieve maximum results once the post-harvest rice begins with the rice harvest. The rice harvest must be supported by a robust transport vehicle in wet and muddy fields. Vehicles with caterpillar drive wheels are compatible because the ground pressure is lower. The design of the rice transport vehicle selects the track wheel type as the drive wheel so that it can be used on wet and muddy surfaces. The vehicle chassis is designed for the transport of 1000-1500 kg of rice. The construction and analysis are simulated with Autodesk Inventor software; the Chasis model is analyzed for strength using the finite element method.
\end{abstract}

Keywords: Rice transport vehicle, Strength analyzed, Finite element analysis

\section{Introduction}

Rice is a plant that is easy to live with in almost every region of Indonesia. Rice is resistant to dry or rainy weather, resistant to pests, easy to grow (one rice stalk can produce eight rice stalks), and relatively quick (four months old). Almost every province in Indonesia has a rice harvesting area that caters to the needs of the population [1].

Merauke Regency is one of the largest rice producers in the Papua Province with a total production of $344,192.32$ tons in 2020, a harvested area of 61,584 ha and a rice productivity of $5.59 \mathrm{t} / \mathrm{ha}$ [2]. The amount of rice production is increasing from year to year according to the New land clearing in\% continues. Agricultural development in Merauke Regency is supported by the availability of agricultural land and the modernization of agricultural tools. The farmers in Merauke currently cultivate rice fields with agricultural machines, from pressure areas for planting, planting, tending to harvesting and post-harvest [3]. The use of agricultural machinery is one way of increasing the productivity and efficiency of agriculture, increasing the quality and added value of products, and empowering farmers. In essence, the use of machines in agriculture consists in increasing the human labor force in the agricultural production process, whereby agricultural tools and machines can be used at any stage of the production process [4]. Therefore, the mechanization of agriculture is expected to increase the efficiency of human labor, the degree and standard of living of farmers, the quantity and quality ofagricultural production, enable the growth of subsistence agriculture to commercial agriculture, and accelerate the transition of economic forms. Indonesia from agricultural to industrial nature [5].

The post-harvest process is the final phase that is the key to success. Therefore, the handling must be done well. In order to achieve maximum results, post-harvest rice begins with the rice harvest, the implementation of which is based on the age of the plant and which is influenced by various factors, namely variety, climate and altitude. Place it so that the age of the rice harvest varies, and the difference is between 5 and 10 days. The characteristics of rice ready to be harvested are when 90$95 \%$ of the grains are pithy or have changed color from yellow to golden yellow. The harvest age is 30-35 days after uniform flowering or after 135-145 days after planting, with the moisture content of the grain in the summer between $22-23 \%$ and $24-26 \%$ in the rainy season [6]. When harvest time comes, farmers will use agricultural tools and machinery that are classified as conventional and modern. Conventional rice harvesters and machines include ani-ani and sickle. Modern rice harvesting tools and machinery include a reaper, a reaper binder, and a combine harvester. In addition to using a rice harvester, a transport vehicle in the form of a hand tractor is also used when transporting rice, with which rice carts are pulled.

\footnotetext{
* Corresponding author :cipto@unmus.ac.id
} 
Hand tractor is the most common vehicle used to transport rice. However, since the drive wheel is a tire wheel type, it is less difficult for the hand tractor to carry rice in the rain, resulting in wet and muddy rice fields. A vehicle that is suitable for transporting rice in the fields is a vehicle with a caterpillar wheel because the pre-ground insurance is less than that of the tire, which allows the vehicle to move well in wet and muddy areas without rice immersion / bedding. The rice transport vehicle design chooses the crwler wheel type as the drive wheel so that it can operate on land with wet and muddy surfaces. The vehicle chassis is designed for $1000-1500 \mathrm{~kg}$ of rice. Design and analysis are simulated using the Autodesk Inventor software. The strength of the Chasis model is analyzed using the finite element method.

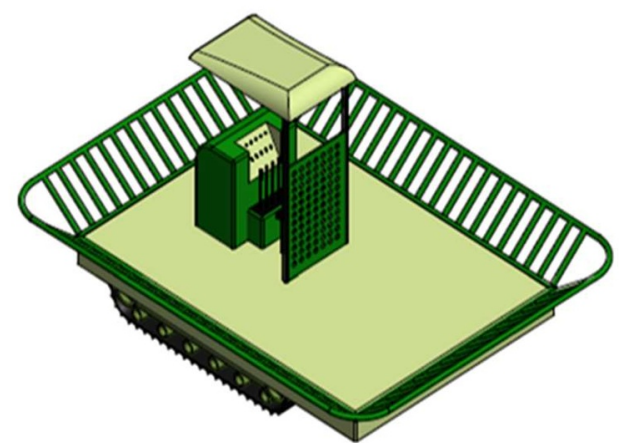

Fig. 1. Rice transport vehicle design

\section{Material and Method}

\subsection{Material Chassis}

Steel is a metal that is widely used in industry. When choosing the chassis material, steel is used for several advantages such as wear resistance, ductility and toughness. Steel is a type of metal that is widely used with the element carbon as one of the basic compounds. According to Ahmed et al. (2017: 431), steel has a good value in terms of yield point and ultimate strength, namely with careful management and processing.

Table 1. Physical Properties of AISI 1018.

\begin{tabular}{|c|c|}
\hline Property & Value 106 HR \\
\hline Young's modulus & $207 \mathrm{Gpa}$ \\
\hline Yield Strength & $250 \mathrm{Mpa}$ \\
\hline Ultimate tensile strength & $354 \mathrm{Mpa}$ \\
\hline Mass density & $7861 \mathrm{~kg} / \mathrm{m} 3$ \\
\hline
\end{tabular}

The steel used is AISI 1018 steel [7]. stated that the AISI 1018 steel material has good toughness, strength, ductility and weldability. The physical properties of the AISI 1018 steel material from design data in Autodesk Inventor Professional software are shown in Table 1 [8]. Information:

Young's modulus $=$ a measure of the stiffness of the material (modulus of elasticity).

$\begin{array}{cl}\text { Yield Strength }= & \begin{array}{l}\text { The starting point for the } \\ \text { plastic deformation of a } \\ \text { material (Stretch limit). }\end{array} \\ \begin{array}{c}\text { Ultimate tensile }= \\ \text { strength }\end{array}=\begin{array}{l}\text { The maximum load the } \\ \text { material can bear } \\ \text { beforehand Breakage } \\ \text { occurs (maximum tensile } \\ \text { strength). }\end{array} \\ \text { Mass density }=\begin{array}{l}\text { The relationship between } \\ \text { the mass of a substance } \\ \text { and its volume (density). }\end{array}\end{array}$

Table 2. Chemical Composition of AISI 1018.

\begin{tabular}{|c|c|}
\hline Composition & Percentage (\%) \\
\hline Carbon ( C ) & $0.14-0.20$ \\
\hline Iron ( Fe ) & $98.81-99.26$ \\
\hline Manganese ( Mn ) & $0.60-0.90$ \\
\hline Phosphorus ( P ) & $<=0.04$ \\
\hline Sulphur ( S ) & $<=0.05$ \\
\hline
\end{tabular}

\subsection{Welding}

The assembly process between parts in chassis modeling uses welding and bolt simulations. The welding takes place on a permanent connection. The weld joint used is a fillet joint. This type of weld joint is used for connections between frames and multiple connections between frames and brackets. Welding has various advantages in the production world, such as economy, dimensional accuracy and variations in the shape of the weld structure. However, welding can also have adverse effects such as: B. Changes in the microstructure, decrease in strength and toughness of the material, deformation and residual stress [9].

\subsection{Autodesk Inventor Professional Software}

Autodesk Inventor Professional 2017 is a type of Computer Aided Drawing (CAD) software that emphasizes solid modeling $[11,12]$. Autodesk Inventor is a parametric 3D modeling software. The term parametric refers to the use of design parameters to create and control the designed 3D model. That is, in order to start creating a design, it is necessary to make a basic sketch with dimensions. These dimensions are used as parameters to control the length and width of the sketchsimulations. 


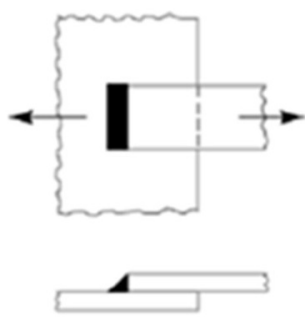

(a) Single transverse.

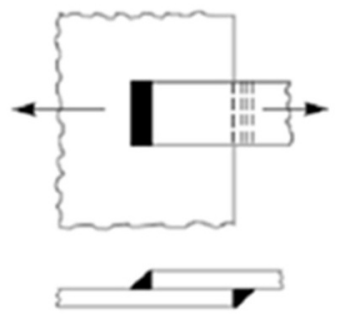

(b) Double transverse.

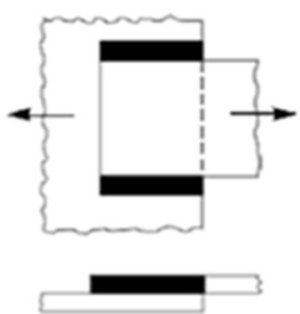

(c) Parallel fillet.

Fig. 2. Fillet joint $[10]$

\subsubsection{Finite Element Analysis}

Finite element analysis (FEA) was used for the modified design and a comparative analysis was performed to check the stress and displacement values [13, 14]. FEA is also known as finite element analysis or finite element method. The way FEA works is to break down a structural object to be tested into finite elements that are interconnected and managed by the software with special calculations. In Autodesk Inventor Professional, the analysis is performed using stress analysis tools. Stress Analysis is a structural test tool in Autodesk Inventor that applies the FEA concept. Stress analysis on the vehicle chassis aims to determine the stress that occurs when the chassis receives a load [15]. country.

\subsubsection{Design Process}

The design process consists of the steps that must be followed in order to manufacture a product. Different or reduced steps lead to different product yields. The design process in designing and analyzing the strength of rice transporting vehicles is computationally performed using Autodesk Inventor software.
The steps to be taken to create the design and strength analysis results on the chassis of the rice transport vehicle are as follows:

a) Literary studies

Literature studies come from previous journals that relate to the research to be carried out. A literature review examines the strengths and weaknesses of existing research in order to be taken into account in the research to be carried out.

b) Design model

The design model is used as a reference before the software is modeled. The design model in the chassis design uses the Pahl and Beitz design models. The design model begins with planning and explaining the product, designing product concepts, designing product shapes, and designing product details.

c) Model

Use Autodesk Inventor Professional 2017 software to design a chassis with a given geometry and determine the type of connection using welding and bolting simulation.

d) Data and material input

This phase is the input o f material data, the determination of restrictions, contacts, meshes and the determination of charging points. Material data is entered in the Autodesk Inventor Professional 2017 software via the material tool. The edge area is determined on the seat, which is directly related to the suspension. It is believed that this seat is rigid with suspension and does not experience displacement due to loading.

\section{Results and Discussion}

The results of the structural analysis when tested with Autodesk Inventor Professional software in the form of von Mises stress, displacement and factor of safety. The report data of this simulation is a computational calculation using the finite element method in stress analysis. Conclusions on structural analysis must correspond to the feasibility standard, the results of the von Mises stress analysis must be below the yield strength value [16]. and the safety factor must be" 4 " [10]. The data obtained from software processing in the form of numerical data, graphs and simulations of von Mises stress, displacement and safety factors found in every geometry from the smallest to the largest. Descriptive analysis is performed to determine the feasibility of a design by ensuring that the design stress does not exceed the allowable stress of the material. The analyzed data is numbers obtained from stress analysis tests in the form of von Mises stress, displacement, and safety factors from Autodesk Inventor Professional software (FEA)

\subsection{Chassis Strength Analysis Results}

The chassis simulation of the transport vehicle is carried out with a total load of $15,000 \mathrm{~N}$. The load analysis is done by determining the weight of each load, which is assumed to be a total weight of $15,000 \mathrm{~N}$ on each side of the vehicle chassis. 


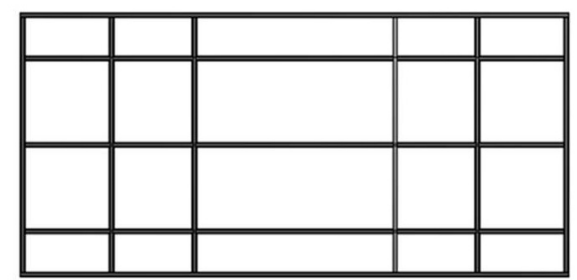

Fig. 3. Top View of Rice Transport Vehicle Chassis

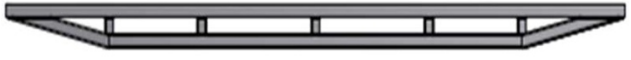

Fig. 4. Side View of Rice Transport Vehicle Chassis

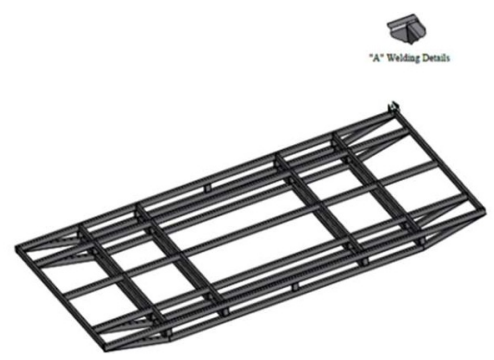

Fig. 5. Connection of the frame using welding

The weld connection used is a fillet weld type. Weld joints of this type are used for connections between frames and some connections between frames and brackets.

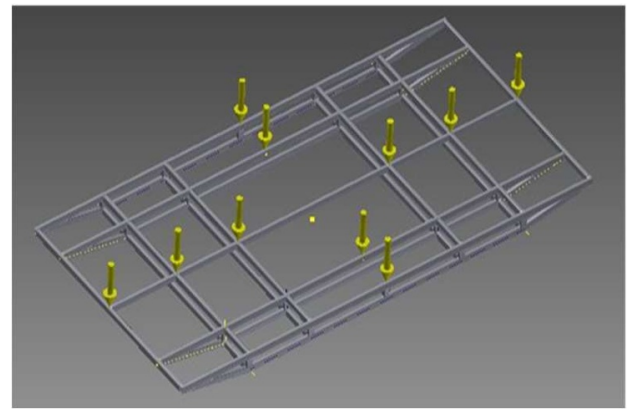

Fig. 6. Load distribution process

\section{Conclusions}

Chassis design with specifications chassis length $6000 \mathrm{~mm}$, chassis width $2500 \mathrm{~mm}$, using AISI 1018 steel material, rectangular model with dimensions 120x80x3mm. The Von Mises stress value for AISI $1018106 \mathrm{HR}$ steel material is $29.06 \mathrm{MPa}$ for the standard mesh, 28.6 MPa for the $10 \mathrm{~mm}$ control mesh and $28.15 \mathrm{MPa}$. The displacement value for AISI 1018 $106 \mathrm{HR}$ steel material is $0.3643 \mathrm{~mm}$ for the standard grid, $0.3704 \mathrm{~mm}$ for the $10 \mathrm{~mm}$ control grid and 0.3764 $\mathrm{mm}$ for the $5 \mathrm{~mm}$ control grid. The safety factor for AISI $1018106 \mathrm{HR}$ steel material is 9.32 for the standard fabric, 9.45 for the $10 \mathrm{~mm}$ control fabric and 9.58 for the control fabric.

\section{References}

1. Idwar, A. Hamzah, and B. Nasrul, "Optimalisasi Pemanfaatan Lahan Marginal Kering untuk Budidaya Padi Gogo di Riau," Unri Conf. Ser. Agric. Food Secur., (2019).

2. BPS Kabupaten Merauke, "Merauke Dalam Angka 2020," Bps Kabupaten Merauke, pp. 1-372, 2020.

3. Harmini, "Strategi Pertanian dan Tanaman Pangan diKecamatan Semangga Merauke," Universitas Hasanuddin, (2011).

4. D. K. S. Swastika, "Teknologi Panen dan Pascapanen Padi: Kendala Adopsi dan Kebijakan Strategi Pengembangan," Anal. Kebijak. Pertan., (2016).

5. "FAKTOR-FAKTOR YANG MEMENGARUHI TOTAL FACTOR PRODUCTIVITY INDUSTRI PERTANIAN INDONESIA PERIODE 19812010," J. Manaj. Agribisnis, (2014).

6. M. Kobarsih and N. Siswanto, "Penanganan Susut Panen dan Pasca Panen Padi Kaitannya dengan Anomali Iklim di Wilayah Daerah Istimewa Yogyakarta," Planta Trop. J. Agro Sci., (2015).

7. P. A, A. Joshi, Hitesh, and Rakesh, "Increase Factor of Safety of Go-Kart Chassis during Front Impact Analysis," Int. J. Innov. Res. Sci. Technol., vol. 3, no. 4, pp. 385-390, (2016).

8. AUTODESK INVESTOR, "Autodesk inventor," [En linea]. Available http//images.autodesk.com/adsk/files/invpro10_det ail_bro_us.pdf, (2016).

9. H. Wibowo, M. N. Ilman, and P. Tri Iswanto, "Analisa Heat Input Pengelasan terhadap Distorsi, Struktur Mikro dan Kekuatan Mekanis Baja A36," J. Rekayasa Mesin, (2016).

10. L. M. Robert, Elemen-Elemen Mesin dalam Perancangan Mekanis, 4th ed. Yogyakarta, 2009.

11. W. L A N, Merancang Komponen Roket 3D dengan Autodesk Inventor Professional 2017, 1st ed. Solo, (2018).

12. Cipto, K. A. Rahangmetan, F. Sariman, Hariyanto, S. B. Bahar, and M. T. Sapsal, "Stress analysis on the frame of peanut skin peeler using autodesk inventor software," in IOP Conference Series: Earth and Environmental Science, (2019).

13. S. K. Gautham Prashanth, M. D. Ragland, and U. Magarajan, "Design and optimisation of roll cage of a single seated ATV," IOSR J. Mech. Civ. Eng. Ver. III, (2015).

14. F. Sariman, Cipto, K. A. Rahangmetan, and S. Asmal, "Analysis of static characteristics of a motorcycle swing arm of a twin-shock suspension type using the finite element method," in IOP Conference Series: Earth and Environmental Science, (2019).

15. S. T, E. . Firmansyah, and I. Naufan, "Perancangan Chasis Tipe Tubular Space Frame untuk Kendaraan Listrik," J. Poros, vol. 15, no. 1, pp. 9-17, (2017).

16. Salimin, Samhuddin, and I. Adha, "Perancangan dan Analisa Simulasi Pembebanan Chassis Sepeda Wisata Untuk Dua Penumpang Menggunakan Software Autodesk Inventor 2017," J. Ilm. Mhs. Tek. Mesin, vol. 3, no. 3, pp. 1-12, (2018). 